\title{
BERAT BADAN INTERDIALISIS TERHADAP ADEKUASI HEMODIALISA PADA PASIEN HEMODIALISA KRONIK
}

Fiora Ladesvita $^{1}$, Lestari Sukmarini ${ }^{2}$

Fakultas Ilmu Kesehatan UPN Veteran Jakarta ${ }^{1}$

Fakultas Ilmu Keperawatan Universitas Indonesia ${ }^{2}$

Email: fiora.ladesvita@upnvj.ac.id ${ }^{1}$; lestari.sukmarini@ui.ac.id²

\begin{abstract}
ABSTRAK
Berat badan interdialisis merupakan hal penting yang perlu diperhatikan dalam menentukan jumlah penarikan cairan selama menjalani proses hemodialisa. Hemodialisa merupakan salah satu terapi pengobatan yang dijalani oleh pasien dengan gagal ginjal kronik. Penambahan berat badan interdialisis akan meningkatkan akumulasi cairan di dalam tubuh pasien yang akan meningkatkan beban awal hemodialisis. Keefektifan hemodialisa dapat dilihat dari perbandingan $\mathrm{Kt} / \mathrm{V}$ dan URR. Metode penelitian yang digunakan adalah observasional analitik dengan pendekatan cross sectional. Sampel yang digunakan adalah pasien yang menjalani hemodialisa kronik yang memenuhi kriteria inklusi dengan total sampel sebanyak 42 orang. Hasil penelitian menunjukkan bahwa ada hubungan yang signifikan dengan arah positif artinya semakin tinggi berat badan interdialisis maka semakin tinggi nilai adekuasi hemodialisa $(r=0,430)$. Dari hasil uji statistik didapatkan bahwa ada hubungan antara berat badan interdialisis dengan adekuasi hemodialisa Kt/V ( $\mathrm{p}$ value $<0,004 ; \alpha 0,05)$. Sedangkan dengan URR, tidak ada hubungan antara berat badan interdialisis dengan adekuasi hemodialisa URR ( $\mathrm{p}$ value $=0,426 ; \alpha 0,05$ ). Nilai V pada Kt/V merupakan volume distribusi urea dalam $\mathrm{ml}$ yang sangat dipengaruhi oleh berat badan interdialisis. Semakin tinggi berat badan interdialisis maka semakin besar volume distribusi urea di dalam tubuh sehingga cairan yang ditarik juga semakin banyak.
\end{abstract}

Kata kunci: Berat badan interdialisis; adekuasi hemodialisa; hemodialisa kronik.

\section{ABSTRACT}

Interdialysis body Weight important to consider in determining the amount of fluid released during hemodialysis process. Hemodialysis is one of therapeutic treatments for patients with chronic kidney failure. Weight gain will increased fluid in the patient's body which is increase the initial weight of hemodialysis. The effectiveness of hemodialysis can be seen from the replacement of $\mathrm{Kt} / \mathrm{V}$ and URR. The research method was observational analytic with cross sectional findings. The sample used was patients who agreed to chronic hemodialysis that appropriate to inclusion criteria and the total sample of this research was 42 people. The results showed that there was a significant relationship with the positive direction meaning that the higher the interdialysis weight, the higher the hemodialysis adequacy value $(r=0.430)$. From the results of statistical tests found that there is a relationship between interdialysis body weight and hemodialysis $K t / V$ adequacy ( $p$ value $<0.004$; $a$ 0.05). Whereas with URR, there is no relationship between interdialysis body weight and hemodialysis URR adequacy ( $p$ value $=0.426 ; a 0.05$ ). $V$ value in $\mathrm{Kt} / \mathrm{V}$ is the volume of distribution of urea in $\mathrm{ml}$ that is strongly influenced by interdialysis body weight. The higher the interdialysis weight, the greater the volume of distribution of urea in the body so that more fluid is also drawn.

Keywords: interdialysis body weight; adequacy hemodialysis; chronic hemodialysis.

Alamat korespondensi: Fakultas Ilmu Kesehatan UPN Veteran Jakarta

Email: fiora.ladesvita@upnvj.ac.id

Nomor Hp: 089637704774 


\section{PENDAHULUAN}

Gagal ginjal kronik merupakan penyakit ginjal tahap akhir yang memerlukan terapi penggantian fungsi ginjal. Prevalensi kejadian gagal ginjal kronik di dunia menurut The United States Renal Data System (USRDS) pada tahun 2013 yaitu laki-laki sebanyak 67.673 jiwa/tahun, dan perempuan sebanyak 49.489 jiwa/tahun. Menurut Indonesian Renal Registry (IRR) tahun 2013 prevalensi penyakit ginjal kronik di Indonesia meningkat pada laki-laki yaitu sebanyak 4.180 jiwa/tahun dan perempuan sebanyak 2.771 jiwa/tahun. Di Propinsi Riau, prevalensi kejadian penyakit ginjal terminal atau ESRD pada tahun 2014 yaitu sebanyak 152 jiwa/tahun. Salah satu terapi penggantian ginjal yang menjadi pilihan adalah hemodialisa. Keefektifan dari tindakan hemodialisa dapat dilihat dari perbandingan $\mathrm{Kt} / \mathrm{V}$ dan URR. Salah satu faktor yang perlu diperhatikan dalam adekuasi hemodialisa yaiotu berat badan interdialisis. Faktor yang memberikan pengaruh yang signifikan terhadap latihan intradialisis dan adekuasi hemodialisa yaitu berat badan interdialisis atau Interdialytic Weight Gain (IDWG). Berat badan interdialisis adalah berat badan antara 2 (dua) waktu proses hemodialisis. Berat badan interdialisis dapat dihitung dengan mengurangi berat badan sebelum HD pada jadwal HD saat ini dengan berat badan setelah HD yang dicapai pasien pada jadwal HD sebelumnya dengan kenaikan berat badan interdialisis yang ditoleransi oleh tubuh yaitu tidak lebih dari 1,0 - 1,5 kg. Menurut Arbor Research Collaborative (2013), penambahan berat badan interdialisis dikelompokkan menjadi tiga yaitu penambahan ringan $(<2 \%)$, penambahan sedang $(2-5 \%)$, dan penambahan berat $(>5 \%)$. Secara pasti belum diketahui hubungan antara berat badan interdialisis dengan adekuasi hemodialisa pada pasien yang menjalani hemodialisa kronik di RSUD Arifin Achmad Pekanbaru. Penelitian ini bertujuan untuk mengetahui hubungan antara berat badan inetrdialisis dengan adekuasi hemodialisa pada pasien yang menjalani hemodialisa kronik.

\section{METODE PENELITIAN}

Metode penelitian yang digunakan adalah observasional analitik dengan pendekatan cross sectional. Sampel yang digunakan adalah pasien yang menjalani hemodialisa kronik yang memenuhi kriteria inklusi yaitu berusia lebih dari 18 tahun, menjalani hemodialisa regular 2 kali seminggu, proses hemodialisa selama 4 jam per sesi dialysis dan bersedia menjadi responden. Total sampel pada penelitian ini sebanyak 42 orang. Sebelum memulai proses hemodialisis, pasien dilakukan penimbangan berat badan. Selisih antara berat badan sebelum hemodialisa saat ini dengan berat badan setelah hemodialisa sebelumnya merupakan berat badan interdialisis. Setelah pasien menjalani hemodialisa, dilakukan penghitungan terhadap adekuasi hemodialisa dengan rumus Kt/V dan URR. Penelitian dilakukan selama 30 hari. Setelah data terkumpul, dilakukan analisis univariate dan bivariate melalui uji korelasi Pearson dan regresi linier sederhana. 
HASIL DAN PEMBAHASAN

Tabel 1. Distribusi frekuensi responden berdasarkan jenis kelamin $(n=42)$

\begin{tabular}{lcccc}
\hline \multicolumn{1}{c}{ Variabel } & \multicolumn{2}{c}{ Frekuensi } & \multicolumn{3}{c}{ Total } \\
\cline { 2 - 5 } & $\mathrm{n}$ & $\%$ & $\mathrm{~N}$ & $\%$ \\
\hline Jenis kelamin & 26 & 61,9 & 42 & 100 \\
$\begin{array}{l}\text { 1. Laki-laki } \\
\text { 2. Perempuan }\end{array}$ & 16 & 38,1 & & \\
\hline Usia & 2 & & & \\
$\begin{array}{l}\text { 1. Dewasa Awal } \\
\quad(18-40 \text { tahun) }\end{array}$ & 26 & 61,9 & 42 & \\
$\begin{array}{l}\text { 2. Dewasa Tengah } \\
\quad(41-60 \text { tahun) }\end{array}$ & 14 & 33,3 & & \\
$\begin{array}{l}\text { 3. Dewasa Akhir } \\
\quad>60 \text { tahun) }\end{array}$ & & & \\
\hline
\end{tabular}

Dari tabel diatas, didapatkan bahwa sebagian besar responden berjenis kelamin laki-laki yaitu sebanyak 26 orang $(61,9 \%)$. Selain itu, sebagian besar responden memiliki usia dalam rentang 41-60 tahun (dewasa tengah) yaitu sebanyak 26 orang $(61,9 \%)$.

Gambaran adekuasi hemodialisa seluruh responden dapat dilihat dari tabel sebagai berikut:

Tabel 2. Analisis responden berdasarkan berat badan interdialisis dan adekuasi hemodialisa $(n=42)$

\begin{tabular}{lccc}
\hline \multicolumn{1}{c}{ Variabel } & Mean \pm SD & Min-Maks & $95 \%$ CI \\
\hline $\begin{array}{l}\text { Berat badan } \\
\text { interdialisis }\end{array}$ & $3,440 \pm 0,558$ & $2,5-4,5$ & $3,266-3,615$ \\
\hline $\begin{array}{l}\text { Adekuasi hemodialisa } \\
\text { 1. Kt/V }\end{array}$ & $1,623 \pm 0,191$ & $1,15-1,96$ & $1,563-1,683$ \\
2. URR & $62,544 \pm 7,094$ & $38,85-75,76$ & $60,333-64,754$ \\
\hline
\end{tabular}

Dari tabel diatas, didapatkan bahwa rata-rata berat badan interdialisis responden yaitu 3,440 $\mathrm{kg}(\mathrm{SD}=0,558)$ dan berada diantara 2,5 sampai dengan $4,5 \mathrm{~kg}$. Selain itu, rata-rata adekuasi hemodialisa dengan perbandingan $\mathrm{Kt} / \mathrm{V}$ responden yaitu $1,623(\mathrm{SD}=0,191)$ dan berada diantara 1,15 sampai dengan 1,96. Sedangkan adekuasi hemodialisa dengan URR yaitu $62,544(\mathrm{SD}=7,094)$ dan berada diantara 38,85 sampai dengan 75,76 .

Tabel 3. Analisis korelasi dan regresi berat badan interdialisis dengan adekuasi hemodialisa $(n=42)$

\begin{tabular}{ccccc}
\hline Variabel & $\mathrm{r}$ & $\mathrm{R}^{2}$ & Persamaan garis & P value \\
\hline $\begin{array}{c}\text { Berat badan } \\
\text { interdialisis }\end{array}$ & 0,430 & 0,185 & $\mathrm{Kt} / \mathrm{V}=2,131-(0,148 \times \mathrm{BB}$ interdialisis $)$ & $<0,004^{*}$ \\
& 0,126 & 0,016 & $\mathrm{URR}=57,03+(1,603 \times \mathrm{BB}$ interdialisis $)$ & 0,426
\end{tabular}

*bermakna pada $\alpha 5 \%$

Dari tabel diatas, didapatkan bahwa hubungan berat badan interdialisis dengan adekuasi hemodialisa $\mathrm{Kt} / \mathrm{V}$ menunjukkan hubungan yang sedang dan memiliki arah positif artinya semakin tinggi berat badan interdialisis maka semakin tinggi nilai adekuasi hemodialisa $(\mathrm{r}=$ 0,430) dimana persamaan garis regresi yang diperoleh dapat menerangkan $18.5 \%$ variasi adekuasi hemodialisa Kt/V. Dari hasil uji statistik juga didapatkan bahwa ada hubungan 
antara berat badan interdialisis dengan adekuasi hemodialisa $\mathrm{Kt} / \mathrm{V}$ ( $\mathrm{p}$ value $<0,004 ; \alpha 0,05)$. Sedangkan dari analisis hubungan berat badan interdialisis terhadap adekuasi hemodialisa URR, didapatkan bahwa tidak ada hubungan antara berat badan interdialisis dengan adekuasi hemodialisa URR ( $\mathrm{p}$ value $=0,426 ; \alpha 0,05)$.

Berat badan interdialisis adalah berat badan antara 2 (dua) waktu proses hemodialisis. Berat badan interdialisis dapat dihitung dengan mengurangi berat badan sebelum HD pada jadwal HD saat ini dengan berat badan setelah HD yang dicapai pasien pada jadwal HD sebelumnya dengan kenaikan berat badan interdialisis yang ditoleransi oleh tubuh yaitu tidak lebih dari 1,0-1,5 kg. Menurut Arbor Research Collaborative (2013), penambahan berat badan interdialisis dikelompokkan menjadi tiga yaitu penambahan ringan $(<2 \%)$, penambahan sedang (2-5\%), dan penambahan berat (> $5 \%)$. Penambahan berat badan interdialisis akan memberikan pengaruh besar terhadap adekuasi hemodialisa, dimana berpengaruh terhadap nilai $\mathrm{V}$ yang merupakan volume distribusi ureum dalam tubuh. Nilai $\mathrm{V}$ diperoleh dari hasil perkalian berat badan pasien dengan estimasi jumlah cairan dalam tubuh (wanita 55\%, pria 65\%). Jadi, semakin tinggi berat badan interdialisis, maka semakin tinggi pula nilai $V$. Nilai $V$ yang tinggi akan mengakibatkan penurunan adekuasi hemodialisa (Mohseni, Zeydi, Ilali, Adib-hajbaghery, \& Makhlough, 2013). Menurut Kamyar dan Kalantar (2009), sebanyak $86 \%$ pasien yang menjalani hemodialisa kronik memiliki berat badan interdialisis lebih dari 1,5 kg. Pasien dengan berat badan interdialisis antara 1,5 sampai $2,0 \mathrm{~kg}$ memiliki resiko kematian $25 \%$ dan pasien dengan berat badan interdialisis lebih dari 4,0 kg memiliki resiko kematian sebesar $28 \%$.

Selama penelitian, peneliti melakukan wawancara terhadap kebiasaan dan kepatuhan pasien terhadap masukan cairan, dan didapatkan kepatuhan pasien terhadap masukan cairan rendah akibat rasa haus yang tinggi dan self efficacy yang rendah, dimana sebagian besar masukan cairan tubuh pasien lebih kurang 800 sampai $1200 \mathrm{ml}$ perhari. Peningkatan berat badan interdialisis pada pasien terjadi akibat ketidakpatuhan terhadap terapi dan pengendalian masukan cairan yang baik. Hal ini sesuai dengan pernyataan Widiyanto, Hadi, dan Wibowo (2013) dimana peningkatan berat badan interdialisis dapat dipengaruhi oleh beberapa faktor seperti masukan cairan, rasa haus, dukungan keluarga dan sosial, self efficacy, dan tingkat stress. Masukan cairan yang berlebih akan meningkatkan berat badan selama periode diantara dialisis. Untuk pasien gagal ginjal terminal yang menjalani hemodialisa, jumlah masukan cairan dibatasi sesuai dengan jumlah urin ditambah dengan nilai Insensible Water Loss (IWL) yaitu 8-10 cc/KgBB/24 jam. Apabila jumlah urin perhari sebanyak $500 \mathrm{ml}$ pada orang dengan berat badan $60 \mathrm{~kg}$, masukan cairan berkisar antara 980$1100 \mathrm{ml}$ perhari (Jungers, 2012).

Dari hasil penelitian, didapatkan bahwa ada hubungan negatif yang sedang antara berat badan interdialisis dengan adekuasi hemodialisa dimana semakin tinggi berat badan interdialisis maka semakin rendah nilai adekuasi hemodialisa. Menurut Daugirdas, Blake, dan Ing (2015), dengan bertambahnya berat badan interdialisis maka akan meningkatkan volume vaskuler dimana fungsi ginjal yang menurun tidak dapat mengeluarkan kelebihan cairan tubuh sehingga cairan yang berlebih akan terperangkap di dalam jaringan dan akan menambah berat badan tubuh. Berat badan sangat mempengaruhi nilai $\mathrm{V}$ dimana nilai $\mathrm{V}$ diperoleh dari hasil perkalian berat badan pasien dengan estimasi jumlah cairan dalam tubuh. Nilai V yang tinggi akan mengakibatkan penurunan adekuasi hemodialisa.

Dari hasil penelitian juga didapatkan persamaan dimana jika berat badan interdialisis naik sebanyak $3 \mathrm{~kg}$, maka dapat diperkirakan adekuasi hemodialisa Kt/V sebesar 1.7. Selain itu, didapatkan pula nilai koefisien dengan determinasi 0.185 yang berarti bahwa persamaan garis regresi yang diperoleh dapat menerangkan $18.5 \%$ variasi adekuasi hemodialisa dan 
sisanya dipengaruhi oleh faktor lain, seperti jenis dialyzer, Qb, Qd, lama waktu dialisis, asupan nutrisi dan cairan selama proses hemodialisis, dan bekuan darah pada sirkuit ekstrakorporeal atau dializer (Chowdhury, Islam \& Zafreen, 2011). Dalam penelitian ini jenis dializer, nilai $\mathrm{Qb}, \mathrm{Qd}$, dan lama waktu dialisis sama diseluruh kelompok responden. Tetapi, dalam penelitian ini asupan cairan dan nutrisi tidak menjadi perhatian peneliti. Menurut penelitian Kara dan Acikel (2009), pada 25 responden yang diberikan asupan cairan dan nutrisi intradialisis berupa 2 buah roti tawar lapis keju dan segelas air teh tanpa gula, didapatkan beda rata-rata adekuasi hemodialisa Kt/V dan URR yaitu sebesar 0.2 dan $4,3 \%$ lebih rendah daripada responden yang tidak mengkonsumsi makanan dan minuman intradialisis. Asupan cairan yang tinggi selama hemodialisa akan mengakibatkan peningkatan pada berat badan post dialisis yang akan berpengaruh terhadap adekuasi hemodialisa, begitu juga dengan asupan nutrisi tinggi protein selama proses hemodialisa akan dapat memberi pengaruh terhadap URR dimana makanan tinggi protein akan menghasilkan sisa metabolisme berupa ureum. Asupan nutrisi selama proses hemodialisa akan dapat menghasilkan nilai URR yang lebih rendah bila dibandingkan dengan yang tidak meningkatkan asupan nutrisi.

\section{SIMPULAN}

Berdasarkan hasil penelitian yang telah diperoleh, dapat disimpulkan :

1. Karakteristik pasien yang menjalani hemodialisa kronik di ruang hemodialisa RSUD Arifin Achmad Pekanbaru yaitu pasien memiliki rata-rata usia 41-60 tahun (dewasa tengah) dengan rata-rata berat badan interdialisis lebih dari 3,44 kg. Mayoritas pasien yang menjalani hemodialisa kronik berjenis kelamin laki-laki.

2. Terdapat hubungan berat badan interdialisis dengan adekuasi hemodialisa $\mathrm{Kt} / \mathrm{V}$ menunjukkan hubungan yang sedang dan memiliki arah positif artinya semakin tinggi berat badan interdialisis maka semakin tinggi nilai adekuasi hemodialisa $(r=0,430)$ dimana persamaan garis regresi yang diperoleh dapat menerangkan 18.5\% variasi adekuasi hemodialisa Kt/V. Dari hasil uji statistik juga didapatkan bahwa ada hubungan antara berat badan interdialisis dengan adekuasi hemodialisa $\mathrm{Kt} / \mathrm{V}$ ( $\mathrm{p}$ value $<0,004$; $\mathrm{a}$ $0,05)$. Sedangkan dari analisis hubungan berat badan interdialisis terhadap adekuasi hemodialisa URR, didapatkan bahwa tidak ada hubungan antara berat badan interdialisis dengan adekuasi hemodialisa URR ( $p$ value $=0,426$; a 0,05).

\section{SARAN}

1. Bagi pelayanan keperawatan, hasil penelitian dapat memberikan tambahan wawasan dan pengetahuan perawat hemodialisa tentang pentingnya monitor intake cairan agar tidak menambah beban kerja ginjal dan mengurangi beban penarikan cairan selama proses hemodialisis.

2. Bagi pendidikan keperawatan, hasil penelitian ini dapat memberikan banyak pengetahuan, bahan diskusi dan bahan pembelajaran bagi institusi pendidikan keperawatan. Dari hasil penelitian ini, instansi pendidikan dan tenaga pengajar dapat mendiskusikan lebih jauh upaya meningkatkan motivasi pasien dalam mengatur intake cairan.

3. Bagi pengembangan penelitian lanjutan keperawatan, hasil penelitian ini juga dapat menjadi referensi bagi perawat maupun peneliti lainnya untuk mengembangkan penelitian selanjutnya tentang terapi lain, atau faktor yang mempengaruhi keefektifan proses hemodialisa pada pasien hemodialisa kronik. 


\section{DAFTAR PUSTAKA}

Chang, Y., et. al. (2010). The effectiveness of intradialytic leg ergometry exercise for improving sedentary life style and fatigue among patients with chronic kidney disease: A randomized clinical trial. Taiwan: International Journal of Nursing Studies.

Chowdury, N., Islam, F., Zafreen, F., Begum, B., Sultana, N., Perveen, S., \& Mahal, M. (2011). Effect Of Surface Area Of Dialyzer Membrane On The Adequacy Of Haemodialysis. Journal of Armed Forces Medical College, Bangladesh, 7(2), 9-11. Retrieved from http:/ / dx.doi.org/10.3329/jafmc.v7i2.10387

Daugirdas, J. T., Blake, P. G., \& Ing,T. S. (2015). Handbook of Dialysis. 5th Ed. Philadelphia: Wolters Kluwer.

Jungers, P. et al. (2012). The Essentials in Hemodialysis: An Illustrated Guide. Retrieved from.https:/ / books.google.co.id/books?id=BY_HBAAAQBAJ\&lpg=PA3\&hl=id\&pg $=\mathrm{PA} 6 \# \mathrm{v}=$ onepage $\& \mathrm{q} \& \mathrm{f}=$ false

Kamyar \& Kalantar, Z. (2009). Interdialytic Weight Gain, Mortality Linked, Nephrology Nursing Journal, February, 18, 2009. http://www.renalandurologynews.com/ interdialytic-weight-gain-mortalitylinked/article/127528/

Kara, B.,\& Acikel, C, H. (2010). The effect of intradialytic food intake on the urea reduction ratio and single-pool $\mathrm{Kt} / \mathrm{V}$ values in patients followed-up at a hemodialysis center. Turk J Med Sci, 40 Suppl, 1), 91-97.

Mohseni, R., Emami Zeydi, A., Ilali, E., Adib-Hajbaghery, M., \& Makhlo, A. (2013). The effect of intradialytic aerobic exercise on dialysis efficacy in hemodialysis patients: A randomized controlled trial. Oman Medical Journal, 28(5), 345-349. http://doi.org/10.5001/omj.2013.99. November 2010, 47(11), 1383-1388. Retrieved from www.ncbi.nlm.nih.gov/pubmed/20537645

The United States Renal Data System (USRDS). (2012). Prevalence of reported CKD on 2013. Diperoleh dari http:/ / usrds.org pada tanggal 10 Oktober 2015.

Widiyanto, P., Hadi, H., \& Wibowo, T. (2013). Korelasi Positif Perubahan Berat Badan Interdialisis dengan Perubahan Tekanan Darah Pasien Post Hemodialisa Positive Correlation of Changing Interdialysis Body Weight with the Changing of Post Dialysis Blood Pressure. Journal Ners and Midwifery Indonesia, 2(1), 1-8. Retrieved from http:// ejournal.almaata.ac.id/index.php/JNKI/article/view/17. 